\title{
LOGIT BUSINESS FAILURE PREDICTION IN V4 COUNTRIES
}

pages: $54-64$

\author{
MAREK DURICA, KATARINA VALASKOVA, \\ KATARINA JANOSKOVA
}

\begin{abstract}
A B S T R A C T
The paper presents the creation of the model that predicts the business failure of companies operating in V4 countries. Based on logistic regression analysis, significant predictors are identified to forecast potential business failure one year in advance. The research is based on the data set of financial indicators of more than 173000 companies operating in V4 countries for the years 2016 and 2017. A stepwise binary logistic regression approach was used to create a prediction model. Using a classification table and ROC curve, the prediction ability of the final model was analysed. The main result is a model for business failure prediction of companies operating under the economic conditions of V4 countries. Statistically significant financial parameters were identified that reflect the impending failure situation. The developed model achieves a high prediction ability of more than $88 \%$. The research confirms the applicability of the logistic regression approach in business failure prediction. The high predictive ability of the created model is comparable to models created by especially sophisticated artificial intelligence approaches. The created model can be applied in the economies of V4 countries for business failure prediction one year in advance, which is important for companies as well as all stakeholders.
\end{abstract}

KEY WORDS

logit, business failure, financial ratios, prediction model, V4 countries

DOI: 10.2478/emj-2019-0033

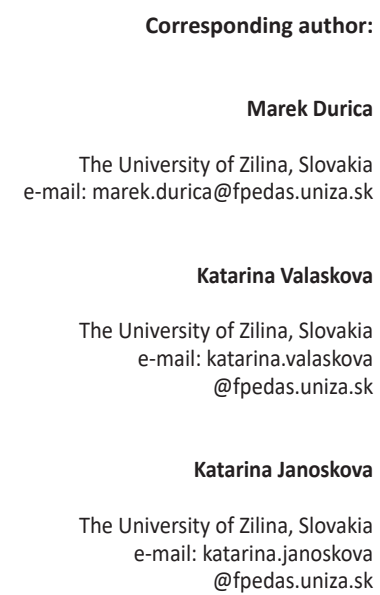

\section{INTRODUCTION}

Financial risk is the possibility that company shareholders will lose money if the corporate cash flows are not sufficient to meet financial obligations. Business failure prediction models are used to eliminate this potential risk. Their task is to evaluate the financial health of the company based on selected financial indicators or other characteristics of the company or the environment in which they operate (Kovacova and Kliestik, 2017).

The main aim of the paper is to present the business failure prediction model for companies that operate in the economics of the Visegrad Group (V4). V4 is a cultural and political alliance of four Central European states - the Czech Republic, Hungary, Poland, and Slovakia. It was established to advance 
military, cultural, economic and energy cooperation among the countries, also furthering their integration in the EU. All V4 nations are post-communist countries with high-income and more or less steady economic growth over the last decades (Visegrad Group, 2019). In these countries, foreign models or national models have been used for business failure prediction. However, generally, they were unaccepted because foreign models tend to be less predictive, and national models have often been developed for specific economic sectors (Kliestik et al., 2018a).

The paper aims to solve the research problem by designing a model of business failure identification. This model is constructed using logistic regression that is one of the most used approaches in this field. During the creation of the best possible Logit model, significant financial and non-financial indicators were identified.

The main contribution of the paper is modelling of business failure of V4 Group companies one year in advance. For model creation, real data of more than $173000 \mathrm{~V} 4$ group companies was used. Therefore, it can be expected that the model has a good representation of the actual specifications of these economics. There is a potential of this model to become a commonly used tool for the prediction of the business failure of companies. The model presented in the paper has a high predictive ability.

The originality of the article lies in the identification of significant determinants in actual post-crisis conditions of the economics in the targeted countries. The model is constructed without regard to any economic sector and any company size. Thus, potential financial risks threatening all companies can be predicted using this model. It can be useful for eliminating potential losses of companies or their stakeholders.

The paper consists of four main parts. The first part presents the literature review, which focuses on the development in the field of business failure prediction models, especially in the economics of the Visegrad Four countries. The section on research methods gives a brief description of data on Polish, Slovak, Czech and Hungarian companies. This section also specifies the principle of logistic regression. The section regarding the results of the research focuses on the description of the created model. Next, based on the analysis of the classification table and the AUC value, the results are discussed and compared, also presenting the analysis of the prediction ability of the model with some prediction models developed in V4 countries.

\section{LITERATURE REVIEW}

Since the first prediction model, developed by Fitzpatrick (1932), researchers created many business failure prediction models, e.g., Altman model (1968), Springate (1978), Ohlson model (1980), Zmijewski model (1984), etc. Based on the reviews of existing models (Kumar and Ravi, 2007; Prusak, 2018; Alaka et al., 2018), two groups of popular tools exist in this field, i.e. statistical tools (multiple discriminant analysis (MDA) and logistic regression (LR) or Logit) and artificial intelligence tools (decision trees, neural networks, etc.). The Ohlson model (1980) was the first prediction model created by logistic regression. Ohlson created a model by using the sample of 105 failed and 2058 healthy firms. Ohlson concludes that the Logit-based model is more useful as MDA-based models (Waqas and Md-Rus, 2018; Bandyopadhyay, 2006; Shumway, 2001; Jones et al., 2016).

In the Czech Republic, the first attempt at developing a national business failure model was made by Neumaierova and Neumaier in 1995, which resulted in the so-called IN95 model (Neumaierova and Neumaier, 2002). In the following years, the same authors built other national models, namely, IN99, IN01 and IN05 using a larger sample of companies. Jakubík and Teplý (2011) developed the first Czech Logit-based business failure prediction model. As the next step, the authors proposed the aggregation of variables identified using this model. On this basis, they established a so-called JT index. This index was aimed at evaluating the financial health of Czech companies operating in the non-financial sector. However, it has been commonly used by companies of all sectors of the Czech economics. Kalouda (2013) proposed another national bankruptcy prediction model. This model comprises key variables from each of the five key models widely discussed in the literature. It also adds a new variable that proxies for the degree of risk diversification within a company. Karas and Režńáková also published the studies on business failure prediction of Czech companies. They built models using linear MDA and the boosted tree method (Režńáková and Karas 2014; Karas and Režňáková 2013, 2014). Using logistic regression, Vochozka et al. (2015) built a highly efficient model for transportation and shipping companies. Of course, many other Czech national models have been developed, e.g., Čámská (2016), Rybárová et al. (2016), etc. 
Hajdu and Virág (2001) developed the first models for business failure prediction in Hungarian companies. The authors used a sample of 154 companies, half of which were insolvent. The models used MDA and LR approaches. Based on the same data, Virág and Kristóf (2005) built a model using artificial neural networks. This model was characterised by higher efficiency compared to previous models. Again, using the same dataset, Virág and Nyitrai (2014) built models using the techniques of support vector machines and the rough set theory. Ékes and Koloszár (2014) estimated models for predicting bankruptcy of Hungarian small and medium-sized companies (SMEs). They used linear discriminant analysis, logit analysis, classification trees, and artificial neural networks. These models were highly efficient, mainly compared to other Hungarian or foreign (Altman, Springate, Ohlson, Zmijewski) models. In 2016, based on data of 1996-2014, Bauer and Endrész (2016) built a probit model for predicting the insolvency of Hungarian companies. In the model, the authors included some macroeconomic variables and qualitative characteristics of companies.

In Poland, the pioneering studies aimed at using foreign models to predict financial distress of Polish companies (Mączyńska, 1994). After that, Gajdka and Stos (1996), Hadasik (1998), Hołda (2001), Hamrol et al. (2004), etc. developed the first Polish national business failure prediction models. Authors created these models based on MDA. Later, the Logit method and some other data-mining methods have been used in many studies presenting Polish national models developed by Gruszczyński (2003), Pisula et al. (2013), Pociecha et al. (2014), Pisula et al. (2015), Brożyna et al. (2016, pp. 93-114). Several studies provide an overview and comparison of existing prediction models (Pawelek et al., 2017; Prusak, 2018; Tokarski, 2018; Wyrobek and Kluza, 2018, Pociecha et al., 2018, Durica et al., 2019).

In Slovakia, the first national models were created using the MDA approach. Gurčík (2002) and Chrastinová (1998) designed models for agricultural companies, but these models were still used to predict the financial difficulties of Slovak companies in various industries. Hurtošová (2009) and Gulka (2016) introduced Slovak Logit models. Kovacova and Kliestik (2017) developed models for bankruptcy prediction of Slovak companies using logit and probit methods and provided the comparison of the overall predictive ability of the developed models. Using the decision tree technique, Karas and Režńáková (2017) and Gavurová et al. (2017) developed a prediction model for companies operating under the conditions of the Slovak economy. Mihalovič (2016) published models for Slovak companies; the first model used an MDA approach and the second - an LR technique.

\section{RESEARCH METHODS}

In this study, to construct a business failure prediction model, logistic regression was used. It is an appropriate statistical method if the dependent variable is categorical (usually, binary). Independent variables can be categorical and continuous. Logistic regression is useful in similar situations as discriminant analysis. However, this method has the advantage related to input assumptions that are less restrictive. It does not require the assumptions of normality of variables or homoskedasticity of individual groups. The classification capability of the logistic regression model tends to be better than in the case of the model obtained from the discriminant analysis. The prediction models created by various artificial intelligence tools usually achieve a slightly higher predictive ability. However, these are mostly so-called black boxes, and, therefore, these models are complicated to interpret. Therefore, these models are not commonly used in practice for business failure prediction (Alaka et al., 2018).

In logistic regression, all independent variables should be linear and independent of each other. Strongly linear relations, i.e. a high degree of multicollinearity among explanatory variables, could affect the stability of the model. Thus, stepwise regression is used to eliminate this risk and select statistically significant variables (Kliestik et al., 2018a).

The data for the study obtained from the database Amadeus - a database of comparable financial information for public and private companies across Europe covering the years 2016 and 2017. The original database consists of real data on almost 450000 companies. After deleting incomplete data, the final dataset consisted of data on 173546 companies.

Similarly, as in Agrawal and Maheshwari (2016), one half of the data was the group of 86773 nonprosperous companies and the second half was the group of 86773 prosperous companies. The selection of prosperous companies was made randomly, while no specifics (economic sector, size, and legal form) were considered. Tab. 1 illustrates the division of companies in all considered countries.

The company was included in the non-prosperous sample if its indicators for 2017 satisfied the fol- 
Tab. 1. Frequencies of prosperous and non-prosperous companies in V4 countries

\begin{tabular}{|l|r|r|r|r|r|}
\hline \multicolumn{1}{|c|}{ Prosperous } & \multicolumn{1}{c|}{ CZECH RePUblic } & \multicolumn{1}{c|}{ HUNGARY } & \multicolumn{1}{c|}{ POLAND } & \multicolumn{1}{c|}{ SLOVAKIA } & \multicolumn{1}{c|}{ TOtaL } \\
\hline Yes & 12423 & 51279 & 6595 & 16476 & 86773 \\
\hline No & 12736 & 46923 & 2698 & 24416 & 86773 \\
\hline Total & 25159 & 98202 & 9293 & 40892 & 173546 \\
\hline
\end{tabular}

Tab. 2. Financial ratios used as potential explanatory variables

\begin{tabular}{|c|l|c|l|}
\hline ID & \multicolumn{1}{|c|}{ METHOD FOR CALCULATION } & ID & \multicolumn{1}{|c|}{ METHOD FOR CALCULATION } \\
\hline X1 & Sales / Total Assets & X20 & Net Income / Sales \\
\hline X2 & Current Assets / Current Liabilities & X21 & Non-current Liabilities / Total Assets \\
\hline X3 & Gross Profit / Total Assets & X22 & Cash / Current Liabilities \\
\hline X4 & Net Income / Equity & X23 & Cash-flow / Current Liabilities \\
\hline X5 & EBITDA / Sales & X24 & Working Capital / Sales \\
\hline X6 & Liabilities / EBITDA & X25 & Current ratio \\
\hline X7 & Net Income/ Total Assets & X26 & Liquidity ratio \\
\hline X8 & Working Capital / Total Assets & X27 & Return on Assets \\
\hline X9 & Operating Profit / Total Assets & X28 & Return on Equity \\
\hline X10 & Total Liabilities / Total Assets & X29 & Shareholder Liquidity Ratio \\
\hline X11 & Current Assets / Total assets & X30 & Solvency ratio (Liability based) \\
\hline X12 & Cash / Total Assets & X31 & Cash-flow / Operating Revenue \\
\hline X13 & Cash-flow / Total Assets & X32 & Net Assets Turnover \\
\hline X14 & Cash-flow / Total Liabilities & X33 & Interest Paid \\
\hline X15 & Current Liabilities / Total Assets & X34 & Gross Margin \\
\hline X16 & Current Assets / Sales & X35 & Profit Margin \\
\hline X17 & Operating Profit / Interest Paid & X36 & Net Current Assets \\
\hline X18 & Stock / Sales & X37 & Working Capital \\
\hline X19 & Cash-flow / Sales & & \\
\hline
\end{tabular}

lowing three conditions: (1) the index of the creditworthiness of the company was less than 0.06 ; (2) the non-prosperous companies were indebted so that the value of liabilities exceeded the value of assets, which meant it had negative equity; and (3) had negative profits after taxes. The inability of a business to generate profits may lead to insolvency (Kliestik, 2018b).

For this study, the values of 37 financial ratios for 2016 served as a basis for the construction of the business failure prediction model (Tab. 2). The indicator of the company size and the indicator of the country, in which the company operated were categorical variables. Therefore, they had to be transformed into dummies. The company size variable (size) had three possible values: small, medium, large and very large. Therefore, it is encoded by two dummies size_Small,size_Large/Very Large. Mediumsized companies were considered a reference category. Similarly, Slovak companies were considered a reference and companies from the other three countries were encoded by three dummy variables country Czech Republic, country_Hungary, and country_ Poland. These dummies, together with the ratios mentioned above, represent the initial set of explanatory variables.

Logistic regression was used to classify the observations (companies) into one of the predetermined groups identified by the dependent variable that could usually obtain only two values. In this study, this dependent variable was Prosperity, representing the non-prosperous companies, denoted by 1 , and prosperous companies denoted by 0 . The goal of the logistic regression was to model and quantify the relationship between the individual characteristics (explanatory variables) and the probability of business failure (or the probability of default).

Fundamentals of logistic regression were used according to Hosmer \& Lemeshow (2000). The principle was given by the logit transformation of the probability of business failure 


$$
p=P(\text { Prosperity }=1):
$$

$\operatorname{logit}(p)=\ln \frac{p}{1-p}=\beta_{0}+\beta_{1} X_{1}+\cdots+\beta_{k} X_{k}(1)$

$\beta_{0}, \beta_{1}, \ldots, \beta_{\mathrm{k}}-$ coefficients estimated from the dataset of companies by maximising the log-likelihood function. Then, the probability of business failure was determined by:

$$
p=\frac{1}{1+\exp \left(-\beta_{0}-\beta_{1} X_{1}-\cdots-\beta_{k} X_{k}\right)}
$$

Based on this probability, the company was classified as prosperous or non-prosperous, using a cutoff score (usually 0.5 ), attempting to minimise the Type I error and the Type II error. The Type I error occurred if the non-prosperous company was classified as prosperous, and the Type II error occurred if the prosperous company was classified as non-prosperous. Frequencies of these errors together with frequencies of correct classification formed the classification table (Kliestik et al., 2018a).

After the logistic model was fitted, testing of its statistical significance could be performed. Usually, the likelihood ratio test is used for this purpose. The non-significance of the model was the null hypothesis of this test. For the assessment of the model quality, various R Square statistics (Nagelkerke R Square, Cox and Snell R Square) were proposed. In this sense, the likelihood statistic $L$ and its modifications: $-2 \ln L$, and the likelihood ratio $G^{2}$ should be used (Hu et al., 2006).

Significance of explanatory variables and related coefficients was provided by the Wald test with the test statistic

$$
z_{\text {Wald }}=\frac{b_{i}}{s_{b_{i}}}
$$

where $b_{i}$ - the estimate of the regression parameter $\beta_{i}$ and $s_{b i}$ - the standard deviation of this estimate. Using this statistic, the null hypothesis, stating that the coefficient equals 0 , was tested. Wald statistic and the Likelihood ratio could also be used to stepwise selection of the significant coefficients and the selection of explanatory variables with a significant impact on the probability of failure (Bewick et al., 2005).

The classification ability of the created logistic regression model was assessed based on the classification table described before. The classification table was used to compare and group the observed and predicted classifications into the categories of prosperous and non-prosperous companies. The table states the absolute and relative frequencies of cor- rectly and incorrectly classified companies as well as the overall classification ability of the model, expressed as the total ratio of the correctly classified enterprises. The company was included in the nonprosperous category if the probability of failure predicted by the model was higher or equal to 0.5 ; otherwise, it was included in the prosperous group.

Also, the classification accuracy of the created model could be assessed based on the ROC curve (Receiver Operating Characteristic curve). The ROC curve gives an image of the behaviour of the established model, regardless of the division of companies into individual groups and regardless of the weight of particular types of incorrect classifications of companies. The vertical axis shows the percentage of nonprosperous companies that were classified correctly in the non-prosperous group, called a true-positive rate or sensitivity. The horizontal axis shows the percentage of prosperous enterprises that were classified incorrectly in the non-prosperous group, called a false-positive rate or 1-specificity (Fawcett, 2006).

The AUC (Area Under Curve) is a frequently used criterion to compare logistic regression models or to assess the classification ability of the created model. The maximum value of AUC is 1, i.e. $100 \%$. Thus, if the size of the AUC is close to 1, then the created model has an excellent classification ability. If the size of the AUC is close to 0.5, the classification ability of the model is not good.

\section{RESEARCH RESULTS}

During the research process, a logistic regression model was designed. This model was created to predict the threat of business failure for one year in advance. Therefore, the dependent variable Prosperity in 2017 and the values of the explanatory variables of 2016 were considered to ensure the correctness of calculations, verification of real data and predictive ability of the model. For the selection of significant explanatory variables, the stepwise forward selection was used, which was based on the Likelihood ratio. Variables size (small, medium and large/very large) and country (Czech Republic, Hungary, Poland, and Slovakia) had to be expressed as dummy variables.

The final model was created in 17 steps, so it contains 17 statistically significant explanatory variables and a constant. For the sake of clarity, only the output characteristics of the final model are illustrated. The Likelihood ratio test checked the significance of the model (Tab. 3). Based on the significance, 
the null hypothesis (the model was not significant) was rejected. Also, the results confirmed the significant contribution of the last ranked variable (X18). As the explanatory variables significantly differentiate the probability of failure, the model can be considered significant.

Tab. 3. Likelihood ratio test results

\begin{tabular}{|l|r|r|r|}
\hline & CHI-SQUARE & DF & \multicolumn{1}{c|}{ SIG. } \\
\hline Step & 3412.372 & 1 & 0.000 \\
\hline Model & 114093.97 & 17 & 0.000 \\
\hline
\end{tabular}

Tab. 4. R Square characteristics

\begin{tabular}{|r|r|r|}
\hline $\mathbf{- 2}$ LOG LIKELIHOOD & \multicolumn{1}{|c|}{$\begin{array}{c}\text { COX \& SNELL R } \\
\text { SQUARE }\end{array}$} & $\begin{array}{c}\text { NAGELKERKE R } \\
\text { SQUARE }\end{array}$ \\
\hline 126491.871 & 0.482 & 0.642 \\
\hline
\end{tabular}

According to value 0.642 of Nagelkerke R Square characteristic (Tab. 4), the model explains more than $64 \%$ of the variability of the logit of business failure probability, which is a rather good value.

Tab. 5 provides an overview of the explanatory variables included in the model, the estimated coefficients related to these variables and the results of the testing of their statistical significance. Only significant variables were included in the model, confirmed by the Sig. column, as the stepwise regression method was used.
We can interpret the logistic coefficients $b_{i}$ (column B) as a change in the value of logit concerning the unit change of the value of the explanatory variable $X_{i}$ provided that values of all other variables stay constant, however, this interpretation is not practical. More practical is the interpretation of coefficients $e^{b i}$ $(\operatorname{Exp}(\mathrm{B}))$. The value of $e^{b i}$ means the number of times when the odds that a company will be non-prosperous changes if the value of the corresponding independent variable changes by a unit and values of other independent variables remain unchanged. If $e^{b_{i}}>1$, the odds increase, if $e^{b_{i}}<1$, the odds decrease. For example, as the value of $X 01$ (Sales to Total Assets) increases by one, the odds that the company will be non-prosperous, will change 1.03 times. Therefore, the odds are $3 \%$ higher. And vice versa, a value of 0.04 for X08 means that an increase in the value of $\mathrm{X} 08$ by one will cause a fall to $4 \%$ of the original odds that the company will be non-prosperous.

Only 12 out of all 37 financial ratios selected as potential predictors (Tab. 1) have a significant impact on probability (or odds) of business failure. For variables X01 (Sales to Total Assets), X10 (Total Liabilities to Total Assets), X18 (Stock to Sales) and X21 (Noncurrent Liabilities to Total Assets), with the increase in the value of these variables, the odds and the probability of failure also increase. On the other hand, the variables X08 (Working Capital to Total Assets), X12

Tab. 5. Description of the developed model

\begin{tabular}{|c|c|c|c|c|c|c|}
\hline VARIABLE & B & S.E. & WALD & DF & SIG. & EXPB \\
\hline country_czech republic & -0.138 & 0.021 & 42.575 & 1 & 0.000 & 0.871 \\
\hline country_hungary & -0.877 & 0.029 & 897.959 & 1 & 0.000 & 0.416 \\
\hline country_poland & -0.599 & 0.037 & 258.852 & 1 & 0.000 & 0.550 \\
\hline size_small & 1.180 & 0.023 & 2562.388 & 1 & 0.000 & 3.255 \\
\hline size_large/very large & -0.863 & 0.072 & 144.810 & 1 & 0.000 & 0.422 \\
\hline X01 & 0.030 & 0.002 & 371.659 & 1 & 0.000 & 1.030 \\
\hline X08 & -3.089 & 0.034 & 8291.102 & 1 & 0.000 & 0.046 \\
\hline X10 & 0.025 & 0.001 & 311.124 & 1 & 0.000 & 1.025 \\
\hline X12 & -0.002 & 0.002 & 1911.917 & 1 & 0.000 & 0.998 \\
\hline $\mathrm{X} 21$ & 0.026 & 0.004 & 54.627 & 1 & 0.000 & 1.026 \\
\hline$X 25$ & -0.017 & 0.001 & 159.794 & 1 & 0.000 & 0.983 \\
\hline X26 & -0.091 & 0.003 & 996.945 & 1 & 0.000 & 0.913 \\
\hline$x 27$ & -1.057 & 0.037 & 819.376 & 1 & 0.000 & 0.348 \\
\hline$x 28$ & -0.966 & 0.016 & 3641.542 & 1 & 0.000 & 0.381 \\
\hline X35 & -1.328 & 0.038 & 1202.718 & 1 & 0.000 & 0.265 \\
\hline X37 & -0.001 & 0.001 & 1093.151 & 1 & 0.000 & 0.999 \\
\hline X18 & 0.042 & 0.002 & 630.457 & 1 & 0.000 & 1.043 \\
\hline constant & 0.107 & 0.025 & 18.568 & 1 & 0.000 & 1.113 \\
\hline
\end{tabular}


(Cash to Total Assets), X25 (Current ratio), X26 (Liquidity ratio), X27 (Return on Assets), X28 (Return on Equity), X35 (Profit Margin) and X37 (Working Capital) have a negative impact on the odds of business failure.

Of course, this interpretation is a little different for continuous explanatory variables (in our case, financial ratios) and dummy variables related to categorical explanatory variables (country and size). For example, in the case of the variable country, Slovakia was considered as a reference category. Odds that a company will be non-prosperous were smaller for companies in all remaining V4 countries. Compared to Slovak companies, companies in Hungary and Poland only had a half of all odds to be non-prosperous, and companies in the Czech Republic had the odds that were $13 \%$ lower. Of course, other company characteristics must be identical.

The probability (odds) of business failure is significantly affected by the size of the companies. Small companies have more than three times higher odds of being non-prosperous compared to medium-sized companies. On the other hand, large and very large companies have only less than half of the odds to be non-prosperous.

The resulting model expresses the logit of the probability of business failure in the form of a linear combination of explanatory variables (column Variable in Tab. 5) with corresponding regression coefficients (column B in Table 5). Using the reverse transformation of logit to probability, we can estimate the probability of business failure by

$$
p=\frac{1}{1+\exp (-Z)}
$$

where

$\mathrm{Z}=0,107-0,138 \cdot$ country_Czech Republic$-0,877 \cdot$ country_Hungary-0,599 . country_Poland+ $+1,180 \cdot$ size_Small-0,863 $\cdot$ size_Large,Very Large + $+0,030 \cdot \mathrm{X} 01-3,089 \cdot \mathrm{X} 08+0,025 \cdot \mathrm{X} 10-0,002 \cdot$ $\cdot \mathrm{X} 12+0,042 \cdot \mathrm{X} 18+0,026 \cdot \mathrm{X} 21-0,017 \cdot \mathrm{X} 25-$ $-0,091 \cdot \mathrm{X} 26-1,057 \cdot \mathrm{X} 27-0,966 \cdot \mathrm{X} 28-1,328 \cdot \mathrm{X} 35-$ $-0,001 \cdot X 37$.

As usual, 0.5 was considered a cut-off point, which meant that if the business failure probability was higher than 0.5 , the company was identified as non-prosperous.

To evaluate the overall accuracy of the estimated model, the classification table (Tab. 6), ROC and AUC were employed. The overall classification ability of our model was more than $88 \%$. This ability was achieved for both prosperous and non-prosperous companies. Thus, the model classifies equally in both groups of companies.

Tab. 6. Classification table

\begin{tabular}{|c|c|c|c|c|}
\hline \multirow{2}{*}{\multicolumn{2}{|c|}{ YES }} & \multicolumn{2}{|c|}{ PREDICTED PROSPERITY } & \multirow{2}{*}{$\begin{array}{c}\text { Percentage } \\
\text { CoRRect }\end{array}$} \\
\hline & & No & & \\
\hline \multirow{2}{*}{$\begin{array}{l}\text { Observed } \\
\text { Prosperity }\end{array}$} & Yes & 76,606 & 10,167 & 88.3 \\
\hline & No & 10,454 & 76,319 & 88.0 \\
\hline & & \multicolumn{2}{|c|}{ Overall Percentage } & 88.1 \\
\hline
\end{tabular}

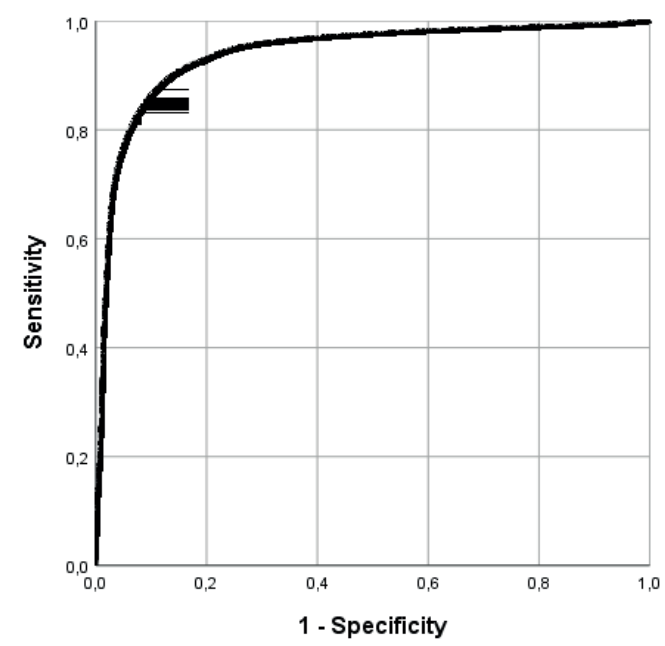

Fig. 1. ROC curve

\section{DISCUSSION OF THE RESULTS}

In the paper, the logistic regression analysis was used to evaluate the future financial situation companies in V4 countries. The results proved that the selected predictors were acceptable for financial risk measurement and business failure prediction. Using the sample of more than 173000 companies (86 773 prosperous and 86773 non-prosperous), a complex prediction model was created with a high overall predictive accuracy of $88.1 \%$ (on the test sample). The shape of the ROC curve and the value of AUC (0.939) proved its validation. However, the research has some limitations. The results of the logistic regression analysis may not be perceived as sufficient compared to other methods (e.g. classification trees, artificial neural networks, etc.). It is the objective for further research to reveal, which method is the most appropriate for business failure prediction in V4 countries.

The results indicate that the developed logit model covers the financial ratios of all four basic groups of financial ratios for activity, liquidity, profitability and debt, which confirms the balance of the developed model. There are four activity ratios (sales- 
to-total-assets ratio, cash-to-total-asset ratio, stockto-sales ratio and working capital), three profitability ratios (ROE, ROA and profit margin), three liquidity ratios (working-capital-to-total-assets, current and liquidity) and two debt ratios (non-current-liabilitiesto-total-assets and total-liabilities-to-total-assets). The coefficient of the working-capital-to-total-asset ratio has the highest impact compared to the other financial ratios in the equation, as it measures the corporate ability to cover its short-term financial obligations. An increasing value of this ratio is usually a positive sign, showing the corporate liquidity improvement over time. Considering the financial ratios of the highest impact in the equation (coefficients more than 1), profit margin and return on equity play an important role. The profit margin ratio shows the percentage of sales left after the business pays all expenses. An extremely low-profit margin indicates the expenses are too high, and the management needs to budget and cut expenses. Return of equity shows how effective corporate management is in generating profit with money the shareholders have invested. The higher the ROE, the more profit a company is making from a specific amount invested, and it reflects its financial health. And vice versa, the more debt a company has, the higher the return on equity ratio.

The importance of the selected financial ratios is underlined by the fact, that the information about the future corporate prosperity eliminates potential financial risks and enables to evaluate the financial health of the company based on selected financial ratios or other characteristics of enterprises or the economic and national environments, in which they operate.

The comparison of the model created in this study with models developed by other authors for the V4 countries demonstrates that it achieves comparable results. Kliestik et al. (2018c) studied business failure prediction in V4 countries using the MDA approach. They formed a prediction model for each V4 country and a complex V4 model based on the same dataset as in the case described in this article. National models achieved higher prediction ability (between $87 \%$ and 93\%) compared to the V4 model with an overall accuracy of $85.9 \%$. The model presented in this paper outperforms these results.

In 2016, using public data from the accounting statements, Němec and Pavlík (2016) created a Logitbased model for predicting the insolvency risk of the Czech companies with a one-year forecast horizon. The authors used data on 2061 Czech companies in total (1 022 healthy companies and 1039 insolvent companies) from 2005 to 2013. Their model works with six financial ratios (from the original 30 ratios) and achieves the overall classification ability of nearly $84 \%$. The model presented in this paper has a better result in this respect.

Brożyna et al. (2016) applied classical linear MDA, LR, classification trees and the method of nearest neighbours for predicting bankruptcy of Polish companies operating in the logistics sector. As predictors, authors used 28 financial indicators of the companies. Their Logit model for predicting bankruptcy for one year in advance achieved a predictive power of $78 \%$ for prosperous companies, and $90 \%$ of non-prosperous companies, and its AUC was 0.95. The model presented in this paper has a very similar classification ability and AUC. However, the model presented in this paper was created based on a much larger data sample. Thus, it can be assumed that this model provides a better reflection of the conditions particular to the Polish economy. From this point of view, the model presented in this paper can be considered a stronger model.

In 2016, two Slovak national bankruptcy prediction models were published by Mihalovič (2016). The first one was estimated using discriminant analysis, while the second was based on logistic regression. Both models were estimated based on a dataset of real 236 companies operating in Slovakia. The results of this study suggest that the Logit-based model outperforms the classification ability of the discriminant analysis-based model. The final Logit model works with only six financial ratios as predictors. However, the predictive ability of this model is less than $69 \%$, and the AUC value is 0.772 . Thus, the model presented in this paper is much more usable in the Slovak economy.

Bauer and Endrész (2016) published a bankruptcy prediction model for Hungarian companies. For the development of this model, the Probit method was used. Authors combined micro- and macro-economic data for 1996-2014. AUC of this model is $86 \%$, and R Square is only about $23 \%$. Even though the authors used a relatively robust sample to fit the model, the model presented in this paper can be considered a better choice.

The mentioned models were created based on national conditions of individual V4 countries. However, mostly, they were created based on older data. The model presented in this paper was based on data for 2016 and 2017. During this period, no significant disturbances in the economies of V4 countries were 
observed. The consequences of the global crisis have already disappeared, so the dataset used in this study reflects the actual conditions of these economies.

Moreover, except for the model by Bauer and Endrész (2016), the models of other mentioned authors do not consider the size of the companies. The model presented in this paper incorporates the information about the size of the company, which proved to be a significant predictor of the probability of financial difficulties of companies. Due to their size, the economic environment and the financial situation of companies can vary considerably, so this information is considered important in the prediction of bankruptcy.

The model is complex and allows predicting business failure in all V4 countries. It allows for easier management implementation. Probably, if individual national models would be created, they would have higher predictive ability. This hypothesis needs to be tested in further research, to reveal which possibility is the most appropriate. Another future research issue is a potential usage of the created model beyond the V4 countries. Given that the model considers the current economic conditions of V4 countries, the lower predictive ability is expected outside these countries.

The issue of financial risk management reveals many possible ways of coping with the risk that affects the financial aspects of companies. One of them is to predict the future financial situation of the company. The results gained in the research are especially important for companies themselves, but also their business partners, suppliers and creditors to eliminate financial and other corporate risks related to the unhealthy or unfavourable financial situation of the company.

Although many business failure prediction models have been created worldwide, the originality and novelty of the proposed model lie in using the logistic regression method while considering the specific post-crisis economic conditions of V4 countries.

\section{CONCLUSIONS}

Based on selected financial indicators or other characteristics of the companies, business failure modelling helps to predict their financial challenges. It provides information about future company prosperity and, thus, eliminates potential financial risks.

Using logistic regression, we identified the statistically significant parameters that reflect the future financial development of the company. Thus, a Logit model was designed to predict potential company failure. The predictors that were identified were sufficiently significant to manage financial risks and to predict the failure of companies operating in V4 countries.

The developed model has some limitations. The relatively low value of the Nagelkerke $\mathrm{R}$ square (64.2\%) means that there is some space for other parameters than can have some impact on corporate prosperity. Also, the choice of the method of logistic regression may not be perceived positively. Despite this, it was possible to identify significant predictors and to achieve a high classification ability of the model.

On the other hand, the results could differ based on the data set. Therefore, the proposed models should be tested in the following years to find out the possibilities for the construction of the business failure prediction model generally accepted considering the economic conditions of V4 countries.

\section{ACKNOWLEDGEMENT}

This research was financially supported by the Slovak Research and Development Agency, Grant NO. APVV-14-0841: Comprehensive Prediction Model of the Financial Health of Slovak Companies, and the Faculty of Operation and Economics of Transport and Communications, University of Zilina, Slovakia, Institutional Grant No. 11/PEDAS/2019: Using selected data mining methods in business failure prediction.

\section{LITERATURE}

Agrawal, K., \& Maheshwari, Y. (2016). Predicting financial distress: revisiting the option-based model. South Asian Journal of Global Business Research, 5(2), 268284. doi: 10.1108/sajgbr-04-2015-0030

Alaka, H. A., Oyedele, L. O., Owolabi, H. A., Kumar, V., Ajayi, S. O., Akinade, O. O., \& Bilal, M. (2018). Systematic review of bankruptcy prediction models: Towards a framework for tool selection. Expert Systems with Applications, 94, 164-184. doi: 10.1016/j. eswa.2017.10.040

Altman, E. I. (1968). Financial Ratios, Discriminant Analysis and the Prediction of Corporate Bankruptcy. The Journal of Finance, 23(4), 589-609. doi: 10.1111/j.1540-6261.1968.tb00843.x

Bandyopadhyay, A. (2006). Predicting probability of default of Indian corporate bonds: logistic and Z-score model approaches. The Journal of Risk Finance, 7(3), 255-272. 
Bauer, P., \& Endrész, M. (2016). Modelling Bankruptcy Using Hungarian Firm-Level Data. MNB Occasional Papers, 122.

Bewick, V., Cheek, L., \& Ball, J. (2005). Statistics review 14: logistic regression. Critical Care, 9(1), 112-118. doi: $10.1186 /$ cc3045

Brożyna, J., Grzegorz, M., \& Pisula, T. (2016). Statistical methods of the bankruptcy prediction in the logistics sector in Poland and Slovakia. Transformations in Business \& Economics, 15(1(37)), 80-96.

Čámská, D. (2016). Accuracy of models predicting corporate bankruptcy in a selected industry branch. Ekonomicky Casopis, 64(4), 353-366.

Chrastinová, Z. (1998). Metódy hodnotenia ekonomickej bonity a predikcie finančnej situácie polnohospodárskych podnikov [Methods of economic creditworthiness evaluation and prediction of financial situation of agricultural companies]. Bratislava, Slovakia: VUEPP.

Durica, M., Frnda, J., \& Svabova, L. (2019). Decision tree based model of business failure prediction for Polish companies. Oeconomia Copernicana, 10(3), 453-469. doi: 10.24136/oc.2019.022

Ékes, K. S., \& Koloszár, L. (2014). The Efficiency of Bankruptcy Forecast Models in the Hungarian SME Sector. Journal of Competitiveness, 6(2), 56-73. doi: 10.7441/joc.2014.02.05

Fawcett, T. (2006). An introduction to ROC analysis. Pattern Recognition Letters, 27(8), 861-874. doi: 10.1016/j.patrec.2005.10.010

Fitzpatrick, P. J. (1932). A Comparison of Ratios of Successful Industrial Enterprises with Those of Failed Firm. Certified Public Accountant, 6, 727-731.

Gajdka, J., \& Stos, D. (1996). The use of discriminant analysis in assessing the financial condition of enterprises. In R. Borowiecki (Ed.), Restructuring in the Process of Transformation and Development of Enterprises. Kraków: Wydawnictwo Akademii Ekonomicznej w Krakowie.

Gavurová, B., Janke, F., Packová, M., \& Prídavok, M. (2017). Analysis of Impact of Using the Trend Variables on Bankruptcy Prediction Models Performance. Ekonomicky Casopis, 65(4), 370-383.

Gruszczyński, M. (2003). Models of microeconometrics in the analysis and forecasting of the financial risk of enterprises. Zeszyty Polskiej Akademii Nauk, 23.

Gulka, M. (2016). Predictive Model of Corporate Failure in the Slovak Business Environment. Forum Statisticum Slovacum, 12(1), 16-22.

Gurčík, L. (2012). G-index - the financial situation prognosis method of agricultural enterprises. Agricultural Economics (Zemědělská Ekonomika), 48(8), 373-378. doi: 10.17221/5338-agricecon

Hadasik, D. (1998). Upadłość przedsiębiorstw w Polsce i metody jej prognozowania [Bankruptcy of enterprises in Poland and methods of its forecasting]. Zeszyty Naukowe. Seria 2, Prace Habilitacyjne, Akademia Ekonomiczna w Poznaniu, 153.

Hajdu, O., \& Virág, M. (2001). A Hungarian Model for Predicting Financial Bankruptcy. Society and Economy in Central and Eastern Europe, 23, 28-46.
Hamrol, M., Czajka, B., \& Piechocki, M. (2004). Enterprise bankruptcy - discriminant analysis model. Przegląd Organizacji, 6, 35-39.

Hołda, A. (2001). Forecasting the bankruptcy of an enterprise in the conditions of the Polish economy using the discriminatory function ZH. Rachunkowość, 5, 306-310.

Hosmer, D. W., \& Lemeshow, S. (2000). Applied Logistic Regression. New York, United States: John Wiley \& Sons.

Hu, B., Palta, M., \& Shao, J. (2006). Properties of $\mathrm{R}^{2}$ statistics for logistic regression. Statistics in Medicine, 25(8), 1383-1395. doi: 10.1002/sim.2300

Hurtošová, J. (2009). Konštrukcia ratingového modelu, nástroja hodnotenia úverovej spôsobilosti podniku [Construction of the rating model as a tool for assessing the creditworthiness of a company] (Dissertation thesis). Bratislava, Slovakia: The University of Economics in Bratislava.

Jakubík, P., \& Teplý, P. (2011). The JT Index as an Indicator of Financial Stability of Corporate Sector. Prague Economic Papers, 20(2), 157-176. doi: 10.18267/j. pep. 394

Jones, S., Johnstone, D., \& Wilson, R. (2016). Predicting Corporate Bankruptcy: An Evaluation of Alternative Statistical Frameworks. Journal of Business Finance \& Accounting, 44(1-2), 3-34. doi: 10.1111/jbfa.12218

Kalouda, F., \& Vaníček, R. (2013). Alternative bankruptcy models - First results. In O. Deev, V. Kajurová, \& J. Krajíček (Eds.), European Financial Systems 2013 Proceedings of the 10th International Scientific Conference (pp. 164-168). Brno, Czech Republic: Masaryk University.

Karas, M., \& Režňáková, M. (2013). Bankruptcy Prediction Model of Industrial Enterprises in the Czech Republic. International Journal of Mathematical Models and Methods in Applied Sciences, 5, 519-531.

Karas, M., \& Režňáková, M. (2017). Predicting the Bankruptcy of Construction Companies: A CART-Based Model. Engineering Economics, 28(2), 145-154. doi: 10.5755/j01.ee.28.2.16353

Karas, M., \& Režňáková. M. (2014). A parametric or nonparametric approach for creating a new bankruptcy prediction model: The Evidence from the Czech Republic. International Journal of Mathematical Models and Methods in Applied Sciences, 8, 214-223.

Kliestik, T., Kliestikova, J., Kovacova, M., Svabova, L., Valaskova, K., Vochozka, M., \& Olah, J. (2018a). Prediction of financial health of business entities in transition economies. New York, United States: Addleton Academic Publishers.

Kliestik, T., Misankova, M., Valaskova, K., \& Svabova, L. (2018b). Bankruptcy prevention: new effort to reflect on legal and social changes. Science and Engineering Ethics, 24(2). doi: 10.1007/s11948-017-9912-4

Kliestik, T., Vrbka, J., \& Rowland, Z. (2018c). Bankruptcy prediction in Visegrad group countries using multiple discriminant analysis. Equilibrium. Quarterly Journal of Economics and Economic Policy,13 (3), 569-593. doi: 10.24136/eq.2018.028

Kovacova, M., \& Kliestik, T. (2017). Logit and Probit application for the prediction of bankruptcy in Slovak 
companies. Equilibrium. Quarterly Journal of Economics and Economic Policy, 12(4), 775-791. doi: 10.24136/eq.v12i4.40

Kumar, P. R., \& Ravi, V. (2007). Bankruptcy prediction in banks and firms via statistical and intelligent techniques - a review. European Journal of Operational Research, 180(1), 1-28. doi: 10.1016/j.ejor.2006.08.043

Mączyńska, E. (1994). Assessment of the condition of the enterprise. Simplified methods. Życie Gospodarcze, $38,42-45$.

Mihalovič, M. (2016). Performance Comparison of Multiple Discriminant Analysis and Logit Models in Bankruptcy Prediction. Economics \& Sociology, 9(4), 101118. doi: 10.14254/2071-789x.2016/9-4/6

Němec, D., \& Pavlík, M. (2016). Predicting insolvency risk of the Czech companies. In M. Reiff, \& P. Gežík (Eds.), Proceedings of the International Scientific Conference Quantitative Methods in Economics: Multiple Criteria Decision Making XVIII (pp. 258-263). Bratislava, Slovakia: The University of Economics in Bratislava.

Neumaierová, I., \& Neumaier, I. (2002). Výkonnost a tržní hodnota firmy [Efficiency and market value of the company]. Prague, Czech Republic: Grada Publishing.

Ohlson, J. A. (1980). Financial Ratios and the Probabilistic Prediction of Bankruptcy. Journal of Accounting Research, 18(1), 109-131. doi: 10.2307/2490395

Pawelek, B., Galuszka, K., Kostrzewska, J., \& Kostrzewski, M. (2017). Classification methods in the research on the financial standing of construction enterprises after bankruptcy in Poland. In F. Palumbo, A. Montanari, \& M. Vichi (Eds.), Data Science Studies in Classification, Data Analysis, and Knowledge Organization. doi: 10.1007/978-3-319-55723-6_3

Pisula, T., Mentel, G., \& Brożyna, J. (2013). Predicting Bankruptcy of Companies from the Logistics Sector Operating in the Podkarpacie Region. Modern Management Review, 20(3), 113-134. doi: 10.7862/ rz.2013.mmr.33

Pisula, T., Mentel, G., \& Brożyna, J. (2015). Non-Statistical Methods of Analysing of Bankruptcy Risk. Folia Oeconomica Stetinensia, 15(1), 7-21. doi: 10.1515/ foli-2015-0029

Pociecha, J., Pawełek, B., Baryła, M., \& Augustyn, S. (2014). Statistical Methods of Forecasting Bankruptcy in the Changing Economic Situation. Kraków, Poland: Fundacja Uniwersytetu Ekonomicznego w Krakowie.

Pociecha, J., Pawelek, B., Baryla, M., \& Augustyn, S. (2018). Classification models as tools of bankruptcy prediction - Polish experience. In W. Gaul, M. Vichi, \& C. Weihs (Eds.), Studies in Classification, Data Analysis, and Knowledge Organization. doi: 10.1007/978-3319-55708-3_18

Prusak, B. (2018). Review of research into enterprise bankruptcy prediction in selected central and eastern European countries. International Journal of Financial Studies, 6(3), 60. doi: 10.3390/ijfs6030060

Režňáková, M., \& Karas, M. (2014). Identifying bankruptcy prediction factors in various environments: A contribution to the discussion on the transferability of bankruptcy models. International Journal of Mathe- matical Models and Methods in Applied Sciences, 8(1), 69-74.

Rybárová, D., Braunová, M., \& Jantošová, L. (2016). Analysis of the Construction Industry in the Slovak Republic by Bankruptcy Model. Procedia - Social and Behavioral Sciences, 230, 298-306. doi: 10.1016/j. sbspro.2016.09.038

Shumway, T. (2001). Forecasting Bankruptcy More Accurately: A Simple Hazard Model. The Journal of Business, 74(1), 101-124. doi: 10.1086/209665

Springate, G. L. V. (1978). Predicting the Possibility of Failure in a Canadian Firm. Burnaby, Canada: Simon Fraser University.

Tokarski, A. (2018). The phenomenon of bankruptcy of enterprises in the polish economy in the years 20082015. In E. Lotko, U. K. Zawadzka-Pak, \& M. Radvan (Eds.), Optimization of organization and legal solutions concerning public revenues and expenditures in public interest (Conference proceedings) (pp. 403-420). doi: 10.15290/oolscprepi.2018.30

Virág, M., \& Kristóf, T. (2005). Neural Networks in Bankruptcy Prediction - A Comparative Study on the Basis of the First Hungarian Bankruptcy Model. Acta Oeconomica, 55(4), 403-426. doi: 10.1556/ aoecon.55.2005.4.2

Virág, M., \& Nyitrai, T. (2014). Is there a trade-off between the predictive power and the interpretability of bankruptcy models? The case of the first Hungarian bankruptcy prediction model. Acta Oeconomica, 64(4), 419-440. doi: 10.1556/aoecon.64.2014.4.2

Visegrad Group (2019, September). About the Visegrad Group. Retrieved from http://www.visegradgroup. eu/about

Vochozka, M., Straková, J., \& Váchal, J. (2015). Model to Predict Survival of Transportation and Shipping Companies. Naše More, 62(3), 109-113. doi: $10.17818 / \mathrm{nm} / 2015 / \mathrm{si} 4$

Waqas, H., \& Md-Rus, R. (2018). Predicting financial distress: Applicability of O-score model for Pakistani firms. Business and Economic Horizons, 14(2), 389401. doi: 10.15208/beh.2018.28

Wyrobek, J., \& Kluza, K. (2018). Efficiency of gradient boosting decision trees technique in Polish companies' bankruptcy prediction. In L. Borzemski, J. Swiątek, \& Z. Wilimowska (Eds.), Advances in Intelligent Systems and Computing Information Systems Architecture and Technology: Proceedings of 39th International Conference on Information Systems Architecture and Technology - ISAT 2018 (pp. 24-35). doi: 10.1007/978-3-319-99993-7_3

Zmijewski, M. E. (1984). Methodological Issues Related to the Estimation of Financial Distress Prediction Models. Journal of Accounting Research, 22, 59-82. doi: $10.2307 / 2490859$ 